Etter sederrevolusjonen i 2005 følte majoriteten av Libanons kristne at de hadde oppnådd mange av sine viktigste mål. Men tiden etter Syrias retrett ble også preget av attentater som i hovedsak rammet kristne områder og kristne, antisyriske journalister og politikere. Demografisk utvikling, mangel på samlende ledere og en voksende islamisme gjør at de kristne føler seg stadig mer usikre.'

\title{
Uro blant de kristne i Libanon
}

Kari Karamé er forsker ved Norsk Utenrikspolitisk Institutt med Libanon, Midtøsten og konflikt og kjønn som spesialfelt. Hun har bodd 17 år i Libanon. 
TEKST: Kari Karamé

SKUFFELSENES ÅR kaller et libanesisk ukemagasin året $2006 \mathrm{i}$ en oversikt over et - selv for Libanon - dramatisk og forvirrende år preget av karikaturstriden i februar, krigen i juli og demonstrasjoner rettet mot regjeringen (som fremdeles pågår). I likhet med alle libanesere er de kristne berørt av den labile situasjonen som rår $\mathrm{i}$ landet, men i tillegg føler de seg truet av en voksende islamisme i den arabiske verden. De ser med frykt på at de kristne menighetene i Palestina og Syria krympes, og at de blir utsatt for angrep i Irak og Egypt. De er seg bevisst at den demografiske utviklingen i Libanon går i mot dem. Denne følelsen av sårbarhet forsterkes av at strid om det politiske lederskapet splitter både den politiske klassen og opinionen. På den ene siden står den såkalte I4. mars-alliansen som omfatter majoriteten av sunni-muslimske, kristne og drusiske ledere. Den ble dannet etter drapet på statsminister Rafik Hariri i februar 2005 og sitter nå med regjeringsmakten. Viktige saker for den er å befri Libanon fra Syrias innflytelse, at en internasjonal domstol oppnevnt av FN skal avgjøre hvem som sto bak attentatet mot Hariri og hittil I8 attentat som har fulgt, at den syriskstøttede presidenten avsettes og at det utskrives valg på ny nasjonalforsamling. Opposisjonen, også kalt 8. mars-alliansen, er ledet av den sjiamuslimske, syriskstøttede organisasjonen Hizbullah, og omfatter majoriteten av sjiamuslimene samt kristne, sunnimuslimer og drusere som av ulike grunner er i opposisjon til regjeringen. For store deler av den kristne opinionen er det spesielt vanskelig å forstå at en av deres fremste ledere, general Michel Aoun, kjent for sitt sterke antisyriske engasjement gjennom mange år, har gått med i denne bevegelsen som har som fremste mål å styrte regjeringen for å danne en samlingsregjering. Hans gruppe vant en overlegen seier under siste valg, men ble ikke invitert med i regjeringen, og mange hevder at det er årsaken til samarbeidet med Hizbullah, men samtidig frykter de at det ikke i lengden er mulig med et samarbeid bare om denne ene saken, og at det kan komme til også å dreie seg om andre av Hizbullahs flaggsaker som videre kamp mot Israel og et nærmere samarbeid med Syria.

\section{Tuftet på flerreligiøs overenskomst}

Et trekk som skiller Libanon fra nabolandene er den religiøse sammensetningen av befolkningen, som er fordelt på hele i8 trossamfunn. Da landet ble selvstendig i I943, var det antatt at det var et flertall av 
kristne, ${ }^{2}$ men den videre demografiske utviklingen har resultert $i$ en fordeling på rundt 60 prosent muslimer og 40 prosent kristne. ${ }^{3}$ Litt forenklet kan en si at det i dag er tre omtrent like store religiøse grupper: kristne maronitter, sunni- og sjiamuslimer, som dominerer landets styre og stell. I tillegg kommer en rekke mindre kristne og muslimske trossamfunn.

Den underliggende ideen for statsdannelsen, som går tilbake til I922 da Libanon og Syria var fransk mandat, var en konsensus (overenskomst) mellom landets ledende menn og familier om at alle trossamfunnene skulle være representert i landets styre og stell i forhold til størrelse og geografisk tilhørighet. ${ }^{4}$ Basert på denne overenskomsten var det fram til I990 en overvekt av kristne representanter i nasjonalforsamlingen, men fordi det alltid har hersket uenighet om hvordan en skulle oppnå en rettferdig representasjon, har antallet seter blitt endret flere ganger. Pres-

\section{Libanon skiller seg fra nabolandene} ved den religiøse sammensetningen av befolkningen, som er fordelt på hele atten trossamfunn.

identen - som var statens leder - skulle allid være maronitt, statsministeren, sunnimuslim og presidenten i nasjonalforsamlingen, sjiamuslim. I oktober I989 inngikk majoriteten av medlemmene av den libanesiske nasjonalforsamlingen, under overoppsyn av Saudi-Arabia og Syria, den såkalte Taif-avtalen. ${ }^{5}$ Den blir betraktet som et sluttpunkt på krigshandlingene som herjet Libanon fra I975 til
I989. ${ }^{6}$ Et viktig punkt i denne avtalen, som erstattet Nasjonalpakten av I943, var bestemmelsen om at setene i nasjonalforsamlingen skulle fordeles likt mellom kristne og muslimer.7 Videre ble makten til republikkens president redusert $i$ forhold til statsministeren og presidenten i nasjonalforsamlingen, og den utøvende makten ble lagt til regjeringen.

Trossamfunnene har hatt ulike holdninger til denne prosessen, og til graden av Libanons arabiske tilhørighet. Maronittene ser på seg selv som grunnleggerne av et selvstendig Libanon, samtidig som de er en del av den romersk-katolske kirken og har pleid nære bånd med Frankrike og Italia i flere hundre år. Den nest største kristne menigheten, den gresk-ortodokse, har sin patriark i Damaskus, og mange var lenge tilhengere av et Stor-Syria. Det samme var store deler av sunni-muslimene og druserne, mens sjia-muslimene har vært seg bevisst at de der ville være en liten minoritet. Samtidig har presteskapet deres i lange tider dyrket nære forbindelser med ayatollaene i Iran. Mange har derfor hevdet at maronittene og sjiamuslimene har en felles interesse $i$ et uavhengig Libanon, men den nære tilknytningen mellom de to ledende sjiamuslimske partiene Amal og Hizbullah og regimet i Damaskus etter I990 har endret på dette.

Et annet trekk som fører til oppsplitting av det libanesiske samfunnet er at hvert trossamfunn har sine egne familielover og religiøse domstoler med myndighet over ekteskap, skilsmisse, barnefordeling og arveoppgjør. Kvinners ulike rettigheter i slike spørsmål er et av hindrene for innføring av en felles, sekulær lov. Mange kristne uttrykker frykt for at hvis de mister mer innflytelse, vil de samtidig miste 
beskyttelsen som de føler at de tradisjonelle, kristne familielovene gir dem. De viser for eksempel til Syria hvor kristne kvinner bare arver halvparten av det deres brødre gjør. Samtidig styrker dette systemet de religiøse myndighetenes innflytelse, og de går i mot innføring av borgerlig ekteskap. Antallet ekteskap mellom kristne og muslimer øker, og mange av disse foretrekker å inngå borgelig ekteskap i utlandet. ${ }^{8}$ De vil da følge loven i det landet de har giftet seg i. Dette er ett av mange eksempler på libanesernes enestående evne til å finne kortsiktige løsninger på problemer som landets politiske og religiøse myndigheter ikke klarer å løse. For øvrig er Libanon overraskende nok det eneste arabiske landet hvor loven tillater en person å konvertere fra islam til kristendom, men det kan være sosialt uakseptabelt.

Religiøse skillelinjer, politiske spenninger Spenninger mellom det som binder sammen og det som splitter, har gjort landet sårbart i forhold til ideologiske strømninger i den arabiske verden, især etter hvert som disse har fått en stadig sterkere islamsk karakter. I frigjøringsprosessen fra tidligere kolonimakter utnevnte den arabiske nasjonalismen Vesten til sin hovedfiende, og de kristne ble sett på som vestliggjorte. Dette skjedde til tross for at flesteparten av dem tilhører de såkalte orientalske kirkesamfunnene ${ }^{9}$ og at politiske ledere, som sjefen for Kataib-partiet (falangistene), Pierre Gemayel, ble fengslet allerede i 1936 for å ha ledet demonstrasjoner med krav om et selvstendig Libanon. Til sammen har dette ført til en svak stat hvor tre omtrent like sterke grupper kjemper om hegemoniet. Internt har nye politiske skillelinjer oppstått og nye politiske allianser har blitt inngått som for kort tid siden ville blitt sett på som unaturlige, som alliansen som ble inngått $i$ februar 2005 mellom general Michel Aoun - som i I989 gikk til krig mot Syria - og den syrisk-støttede organisasjonen Hizbullah. Spenningen mellom konsensus og konflikt har preget Libanons nyere historie $^{\text {Io }}$ og vært rammen om vanlige libaneseres liv, og er antagelig en av årsakene til at de søker tilflukt i sin egen gruppe, basert på religion og familie, og i stor grad følger den regionale lederen. Det kristne lederskapet framstår i dag som splittet og svekket, noe som kommer spesielt tydelig fram med hensyn til Kataib-partiet. ${ }^{\text {II }}$ Det var i flere tiår Midtøstens største parti, men er i dag delt opp i flere fraksjoner.

Ifølge Taif-avtalen skulle alle militser avvæpnes, men siden Hizbullah definerte seg som en frigjøringsbevegelse - og siden Israel fortsatte sin okkupasjon av SørLibanon - fikk de beholde våpnene sine. Syria benyttet deler av avtalen til å befeste sin kontroll både over landets økonomi, politikk og forsvar. ${ }^{\text {I2 }}$ Mange valgte å innfinne seg med den nye situasjonen, mens andre, i første omgang kristne politikere og intellektuelle, opponerte mot Syrias økende innflytelse i landet. General Michel Aoun ble sendt i asyl i Frankrike, tidligere president Amin Gemayel søkte også tilflukt der, mens Samir Geagea, lederen av den hovedsakelig kristne militsen De libanesiske styrkene, ble fengslet som den eneste libanesiske militslederen. Noen få valgte et slags indre eksil eller isolasjon, avskåret fra all politisk virksomhet og adgang til media. I årene som fulgte, forlot mange kristne tidligere militssoldater landet. I den kristne opinionen vokste inntrykket av at de var de 
eneste som måtte oppfylle betingelsene i Taif-avtalen. Universitetene ble i årene fram til sederrevolusjonen de viktigste arenaene for meningsutveksling om Syrias innflytelse, og studenter som sympatiserte med Aoun og Geagea ble de viktigste aktørene. Mange ble banket opp og havnet i arresten. I de kristnes kollektive minne ble dette forbundet med massakre i Damour (I976), Qa'a (I979) og Shuf-fjellene (I979 og I984), ${ }^{\text {,3 }}$ og de uttrykte $\sin$ sterke misnøye med de som styrte landet, ved å boikotte valgene i I992 og I996.

\section{Drapet på Hariri og Syrias retrett}

Den hendelsen som førte til at situasjonen totalt endret seg, og at majoriteten av kristne og sunni-muslimer kom til å stå på samme side i kampen for å befri Libanon for det de kalte "det syriske åket", var at den syrisk-støttede presidenten Emile Lahoud i 2004 fikk sitt mandat forlenget $i$ tre år. Det var mange kristne som hadde store håp til

\section{Majoriteten av libaneserne mener at} staten er den eneste som kan bestemme over krig og fred, og at Hizbullah bør gi fra seg våpnene.

Lahoud, da han ble valgt seks år tidligere, om at han skulle forsvare deres interesser og fremme Libanons uavhengighet ved å sende den libanesiske hæren til SørLibanon slik at Hizbullahs stilling der ville svekkes. Etter hvert som det ble klart at han ikke kunne levere, ble han mer og mer isolert $\mathrm{i}$ forhold til de kristne. Samtidig ble forholdet mellom han og statsminister Rafik Hariri mer og mer tilspisset og endte i totalt brudd etter at Lahoud hadde fått sitt mandat forlenget. I oktober samme år fant det første attentatet mot en motstander av Syrias innflytelse sted, og den I4. februar 2005 ble Hariri og 22 andre personer drept av en kraftig bilbombe. Det var et varsel om de mange attentatene som skulle ramme Libanon i årene framover. Fortsatt er det ikke klart hvem som står bak disse attentatene, men mange peker mot regimet i Damaskus og deres agenter i Libanon. 7. april 2005 vedtok FNS sSikkerhetsråd enstemmig resolusjon I595 som ber om en etterforsking av drapet på Hariri. ${ }^{\text {I5 }}$ Resultatet av denne, som er preget av at åstedet ble "ryddet" før kompetent teknisk personell kom til, ble publisert i den såkalte Mehlis-rapporten den 20. oktober samme år, ${ }^{16}$ og selv om den ikke trekker klare konklusjoner, peker den på nødvendigheten av å avhøre personer på høyeste hold i Damaskus. Fire libanesiske generaler som var utpekt av syrerne for å lede libanesiske etterretningstjenester, ble arrestert og sitter fortsatt i fengsel. Etterforskningen pågår fortsatt og omfatter nå alle attentater, også de som er begått mot vanlige borgere, slik som ved bussbombene I3. februar 2007. Den siste rapporten ble presentert for FNS generalsekretær i januar 2007, og det er nå bare den syriske presidenten som ikke har latt seg avhøre. ${ }^{\text {17 }}$ Når etterforskningen er endelig avsluttet, skal den presenteres for en internasjonal domstol oppnevnt av FNS sikkerhetsråd. I Libanon hersker det stor uenighet om denne domstolen. Regjeringen støtter den, mens presidenten nekter å underskrive på det nødvendige dokumentet for å få saken opp til avstemning $\mathrm{i}$ nasjonalforsamlingen. Det er vanskelig å

Stedet der statsminister Rafik Hariri ble drept i Beirut. 


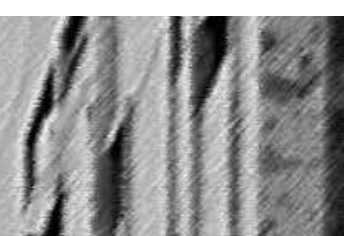

Nou

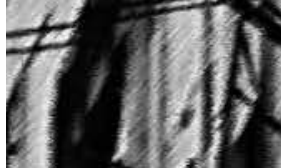

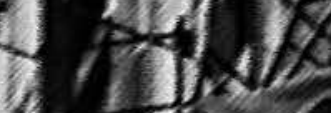

tr 1 in

if) $/$ (

2.

( )
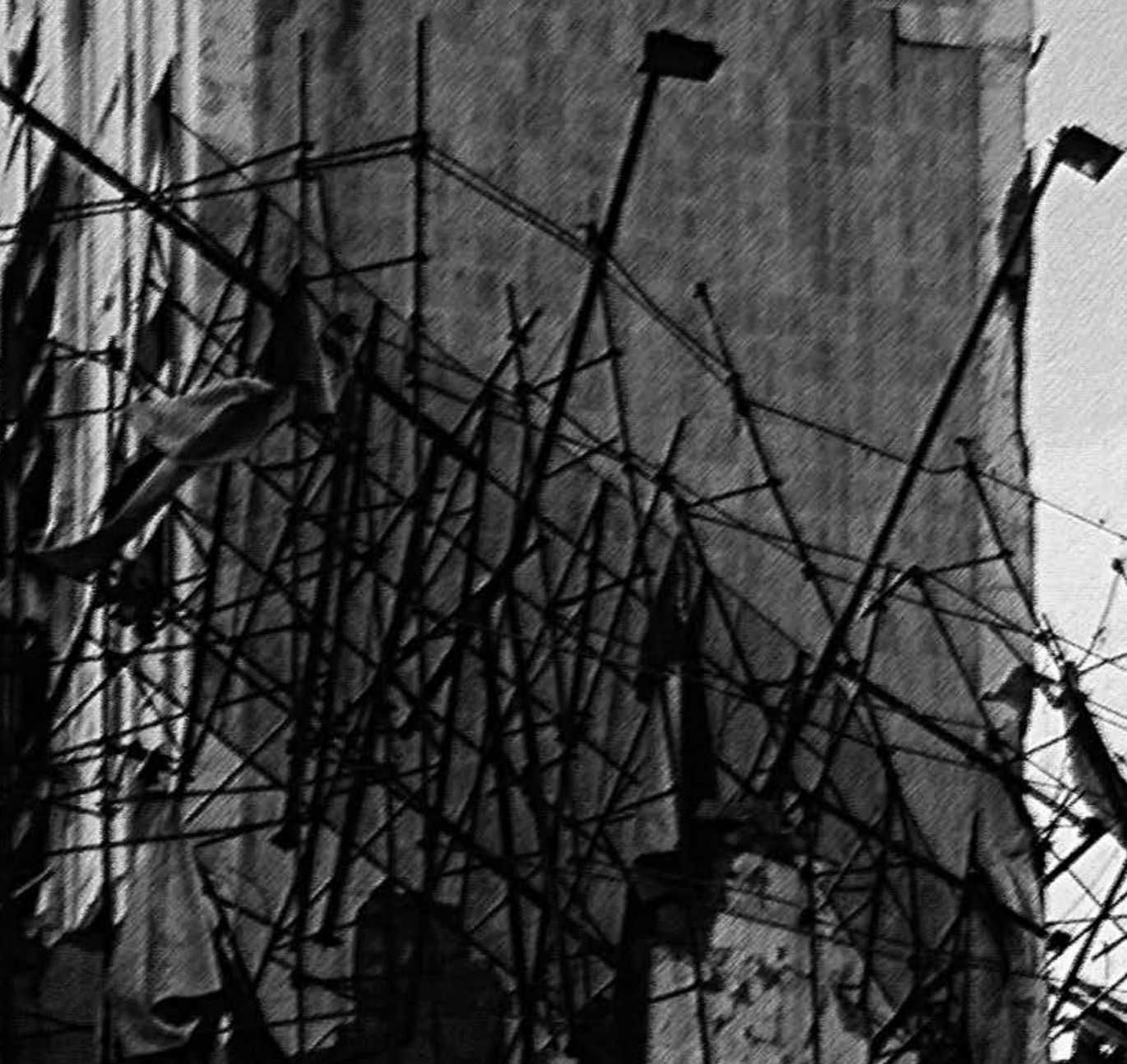

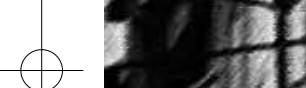
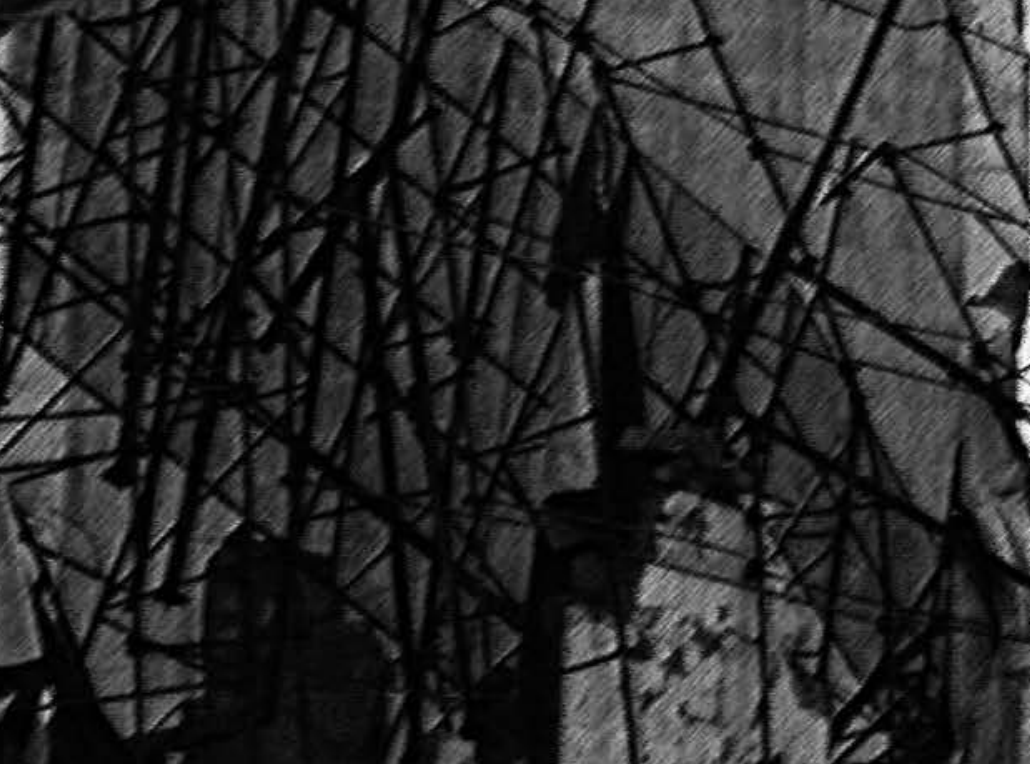
se hvordan det libanesiske samfunnet skal kunne overkomme skillelinjer og mistro ofte basert på uetterrettelige rykter - hvis rettsaken ikke skulle finne sted.

Drapet på Hariri førte til enorme spontane demonstrasjoner i sentrum av Beirut. Den største fant sted I4. mars 2005 og samlet vel en million mennesker fra alle lag av befolkningen som krevde sannheten om hvem som sto bak attentatet, at Syria måtte trekke seg ut og presidenten gå av. Uken før, den 8. mars, hadde Hizbullah arrangert en massedemonstrasjon hvor frigjøringskampen mot Israel var det mest sentrale temaet. Begge demonstrasjonene brukte stort sett bare nasjonale symboler og dempet ned de religiøse, allikevel var det tydelig at en allerede her sto overfor to ulike samlinger som etter hvert har kommet til å bruke de to datoene som merke. I4. mars står for de som støtter regjeringen, også kalt lojalistene, og samler majoriteten av sunnimuslimer, kristne og drusere. Hariri-familien har en sentral stilling i denne koalisjonen. 8. mars står på sin side for opposisjonen og omfattet i første omgang sjiamuslimer og grupper med annen religiøs tilhørighet, men som var uenige med regjeringen, blant annet i spørsmålet om samarbeidet med Syria. Hizbullah er den mest aktive kraften i denne koalisjonen og har på den måten sørget for å skaffe seg en sentral plass på den nasjonale politiske arenaen. ${ }^{\mathrm{I}}{ }^{8}$

Bare kort tid etter drapet på Hariri ble det arrangert valg på ny nasjonalforsamling, og Fouad Siniora, som i mange år hadde samarbeidet nært med Hariri både i privat og etter hvert i politisk sammenheng, ble bedt om å danne regjering. Den kom til å bestå av representanter for I4. mars-koalisjonen og Hizbullah som senere flere ganger har gått ut av og inn i regjeringen. General Aouns gruppe ble imidlertid utelatt, til tross for at de, ifølge deres egne beregninger, representerer 70 prosent av den kristne velgermassen. Aouns tallrike støttespillere, som hadde vært meget aktive i lojalistenes demonstrasjoner, reagerte svært negativt på at de ikke kom med i regjeringen. De følte at verken valg eller ny regjering hadde ført til vesentlige endringer og stiller derfor spørsmål ved regjeringens legitimitet. I februar 2006 offentliggjorde aounistene og Hizbullah en intensjonsavtale som omfatter flere politiske saker, men som ikke sier noe om den internasjonale domstolen. I mai demonstrerte de for første gang sammen mot regjeringen.

Dette har ført til at mange kristne stiller spørsmål ved general Aouns politiske agenda og til åpen strid spesielt mellom hans gruppe og tilhengerne til Samir Geagea. Aoun deltok imidlertid i forsøkene på å få i gang en nasjonal dialog i mars. Stadig skiftende allianser og motstridende politiske signaler fører til forvirring og usikkerhet om hva som er det egentlige målet: Søker Hizbullah bare å splitte den kristne opinionen, eller er det Aouns (eventuelle) ambisjoner om å bli landets neste president som ligger bak?

\section{Frontene hardner til}

Men det er en annen hendelse som har sendt virkelige sjokkbølger gjennom den kristne befolkningen. Søndag 5. februar 2006 ble helgefreden brutt av at sunnimuslimske islamister toget mot den danske ambassadens lokaler for å protestere mot Jyllandspostens publisering av karikaturer av profeten Muhammed. Ambassaden ligger et snaut kvartal inne i 
den, i hovedsak, kristne bydelen Ashrafieh, regnet fra sentrum i Beirut. Allikevel valgte demonstrantene å ta seg fram via gatene inne $\mathrm{i}$ bydelen mens de ropte islamistiske slagord og veivet med islams grønne flagg. Bygningen hvor ambassaden lå og en boligblokk ved siden av ble satt i brann, forretninger ble ranet og biler knust, og det aller mest skremmende for beboerne var at en

\section{rm \\ De kristne ser på den voksende islamismen $i$ arabiske land som en trussel mot det flerreligiøse Libanon.}

kirke ble angrepet midt under gudstjenesten og korset over inngangen til hovedsetet til den gresk-ortodokse erkebiskopen ble profanert. Til overmål måtte de skrekkslagent være vitne til at sikkerhetsstyrkene flyktet unna demonstrantene i stedet for å beskytte dem. Det hjalp lite at innenriksministeren gikk av dagen etter de følte seg overlatt til seg selv, og enkelte fant fram håndvåpnene som de hadde gjemt bort siden I990.

Israels katastrofale angrep mot Libanon i juli-august 2006 fikk tilsynelatende alle motsetninger til å opphøre. Forholdet til Israel har splittet libaneserne siden denne staten ble grunnlagt og store mengder palestinske flyktninger måtte slå seg ned i landet. Israel er på mange måter antitesen til det flerreligiøse Libanon og har derfor ikke framstått som en modell på samme måte som ideen om et Stor-Syria. Men flere libanesiske militser fikk våpen og trening fra Israel, især Den sørlibanesiske hæren, som ble dannet av en kristen major, men hvor de fleste soldatene etter hvert var sjia- muslimer. Den ble oppløst etter at Israel trakk seg ut av Libanon i mai 2000. Derimot var forholdet mellom Israel og De libanesiske styrkene, som var basert i Beirut, aldri så tett og kjølnet etter den israelske invasjonen i I982, etter hvert som interessemotsetninger kom fram. I motsetning til Syria har Israel aldri hatt noen langvarig innflytelse over det politiske livet i Libanon, bortsett fra i Sør-Libanon under okkupasjonen fra I982 til 2000. Selv om mange anklager Hizbullah for å ha forårsaket angrepet fra Israel i juli 2005 ved å angripe en israelsk patrulje og bortføre to israelske soldater, står libaneserne samlet $\mathrm{i}$ fordømmelsen av de overdrevne motangrepene fra israelsk side. Det erklærte målet bak disse var å sette Libanon 20 år tilbake og utrydde Hizbullah. Angrepene førte til enorme materielle ødeleggelser, men framfor alt var det, som vanlig, den sivile befolkningen det gikk ut over. Mer enn I200 ble drept, av disse var I/3 barn under I2 år, og vel 4400 ble såret, og endelig mistet mer enn 200 oo० personer hjemmet sitt. Flesteparten av disse ofrene var sjiamuslimer, men det var også drusere, sunnimuslimer og kristne blant dem.

Men konsekvensene av terrorbombingen har rammet hele landet i form av økonomiske tilbakeslag og økt arbeidsledighet. Etter I990, og spesielt etter fredsforhandlingene i Madrid i I99I, tok regjeringen opp store lån i utlandet for å betale en ambisiøs gjenoppbygging av landet. Det påførte Libanon en statsgjeld på 40 milliarder USD som landet har hatt store problemer med å betjene. Det er på denne bakgrunnen en må se de enorme tapene Israel påførte landet i løpet av noen korte sommeruker: foruten de nevnte human- 
itære konsekvenser steg arbeidsledigheten til 20 prosent. I tillegg kommer enorme ødeleggelser av offentlig infrastruktur. I tiden etter at angrepene opphørte og fram til 31. desember 2006 hadde 100000 libanesere forlatt landet for godt, ${ }^{\text {I9 }}$ framfor alt unge mennesker med universitets- eller yrkesutdanning. Sjokket og konsekvensene har rammet så hardt at alle enstemmig fordømmer Israel. Men der stopper også enigheten - majoriteten av libaneserne med statsministeren i spissen mener at staten er den eneste makten som kan bestemme over krig og fred, og at Hizbullah derfor bør gi ifra seg våpnene. Hizbullah, på sin side, tolker det som skjedde som en guddommelig seier, og hevder at de derfor bør ha større politisk innflytelse. I dette kravet støttes de av Iran og Syria, både politisk, økonomisk og med våpen. ${ }^{\circ}$

Da den kristne industriministeren Pierre Gemayel ble drept i november 2006, ble dette oppfattet som et nytt slag mot regjeringen og mot ideen om et uavhengig Libanon. Mange stilte spørsmålet om hvorfor det igjen var en kristen politiker som ble drept. Han hadde nedlagt mye arbeid i å vekke til live Kataib-partiet igjen. Kunne det være grunnen - var det ikke tillatt for kristne å ha en sterk ledelse? Samtidig trådte splittelsen blant de kristne fram siden aounistene og andre kristne fraksjoner ikke deltok i sørgehøytidelighetene. Frontene blir alltid ekstra harde når folk som har stått sammen, havner på hver sin side. Og splittelsen ble enda tydeligere da opposisjonen, med Hizbullah i spissen, fulgt av general Aoun og sunnimuslimske fraksjoner, startet en sit-in i sentrum av Beirut. Målet var å kaste den sittende regjeringen for å innføre en nasjonal samlingsregjering hvor opposisjonen skulle ha en tredjedel av plassene og dermed vetorett. Mange antar at denne eventuelt skal brukes til å forhindre opprettelsen av den internasjonale domstolen hvis oppgave skal være å avgjøre hvem som sto bak drapet på Rafik Hariri. FNs sikkerhetsråd har gitt sin støtte til etableringen av domstolen. ${ }^{2 \mathrm{i}}$ Et spørsmål som reises, er hvorvidt tribunalet, i mangel av libanesisk ratifisering, eventuelt vil kunne vedtas opprettet ved en sikkerhetsrådsresolusjon med henvisning til FN-charterets kapittel syv. ${ }^{22}$ General Aoun hevder at det bare er tale om rekkefølge, og at den nasjonale samlingsregjeringen er opposisjonens eneste mål. Men majoriteten av de kristne - også flere og flere av hans egne tilhengere - spør seg om han ikke er en brikke $i$ et større regionalt spill ved å gi det en tverr-religiøs legitimitet.

Det er mange og sammensatte årsaker til uroen blant de kristne i Libanon, og som fører til at mange, især de unge med utdanning, velger å skape seg en framtid andre steder i verden. Noen bekymringer deler de med resten av den libanesiske befolkningen, andre henger sammen med at de $\mathrm{i}$ økende grad føler at de tilhører en utsatt minoritet i Midtøsten. Ifølge meningsmålinger regner over 60 prosent med at de vil leve et annet sted i verden om ti år. Det er en gjengs oppfatning at dette især gjelder de kristne fordi de i gjennomsnitt har høyere utdanning og fordi de, som kristne, har lettere for å tilpasse seg et liv i vestlige land. Om dette er riktig eller ikke, spiller egentlig ingen rolle, for uansett bygger det opp under en følelse av at framtiden ligger et annet sted, noe som understrekes av de kristnes kollektive minne. De ser på den voksende islamismen i arabiske land, både blant sjia- og sunnimuslimer, som en 
trussel mot det flerreligiøse Libanon, bygd på konsensus. Og framfor alt savner de et samlet og samlende lederskap.

\section{- $f \cdot$}

I I tillegg til oppgitte kilder bygger dette innlegget på egne notater fra samtaler og observasjoner gjort under flere lengre opphold fra 2004 til januar 2007.

2 Dette bygde på en svært omdiskutert folketelling i I936.

3 https://www.cia.gov/cia/publications/factbook/geos/le. html\#People

4 Kamal Salibi: «A House of Many Mansions. The history of Lebanon reconsidered», I.B. Tauris \& Co Ltd., London I988 og Roger Scruton: «A Land Held Hostage. Lebanon and the West». The Claridge Press, London I987.

5 Den fikk sitt navn etter byen Taif i Saudi-Arabia hvor forhandlingene foregikk.

6 For en grundig oversikt over krigens forløp og skiftende allianser anbefales Theodor Hanf: «Coexistence in wartime Lebanon. Decline of a State and Rise of a Nation». The Centre for Lebanese Studies \& I.B.Tauris \& Co Ltd., London I993.

7 Det er flere kristne trossamfunn enn muslimske, derfor har de flere seter enn det totale antallet kristne skulle tilsi. Geografisk fordeling av sunniene giør at de har flere seter enn sjiamuslimene.

8 Det har vært umulig å finne noen statistikk på dette, men det skjer bl.a. på universitetene og store arbeidsplasser.

9 Maronittene er tilknyttet den romersk-katolske kirken og ser på paven som sitt åndelige overhode. Samtidig har de sin egen patriark og stor grad av indre selvstyre. De bruker arameisk eller arabisk under gudstjenesten.

Io Nadim Shehadi and Dana Haffar Mills: «Lebanon. A history of conflict and consensus». The Centre for Lebanese Studies and I.B.Tauris \& Co Ltd Publishers, London I988.

II Frank Stoakes: "The Lebanese Kataeb Party as a builder, surrogate and defender of the State", i Middle Eastern Studies, II:3, I975, S.215-36, og Theodor Hanf: «Coexistence in Wartime Lebanon.

I2 Joseph Maïla: "L'accord de Taëf deux ans après", Les Cahiers de l'Orient, no. 24, I99I.

I3 Aïda Kanafani-Zahar: "La réconciliation des druzes et des chrétiens du Mont Liban ou le retour à un code coutumier", i Critique internationale no 23 - april 2004, s. 5575.

I4 Harik, Judith: "Democracy Derailed: Lebanon's Ta'if Para dox," i Bahjat Korany, Rex Brynen and Paul Noble (red.) «Political Liberalization and Democratization in the Arab World», Vol. II: "Arab Experiences”. Lynne Rienner, Boulder, CO, I998; samme forfatter: "Citizen Disempowerment and the I996 Parliamentary Elections in the Governate of Mount Lebanon", i Democratization, 5, I (Vår I998) s. $158-82$.
I5 United Nations Security Council Resolution I595, 2005.

I6 United Nations Security Council, "Letter dated 20 October 2005 from the Secretary-General addressed to the President of the Security Council", 2005.

I7 United Nations Security Council, "Letter dated 24 January from the Secretary-General addressed to the President of the Security Council", 2005.

I8 Se bl.a. "Lebanon at the crossroads" i Middle East International, No. 746, I8. mars 2005 og Georges Corm: "Crise libanaise dans un contexte regional houleux", i Le Monde diplomatique, april 2005 .

I9 L'Orient Le Jour, Beirut, I7.0I.07, referat fra UNDP-konferanse om det sivile samfunnets rolle i Libanon, refererer til "offisielle kilder".

20 I2. februar 2007 ble en lastebil full av våpen og ammunisjon stanset i utkanten av Beirut. Hizbullah gjorde krav på den. Det har vakt bekymring at lasten inneholdt raketter som var for små til å nå Israel. Dette fikk bred dekning i libanesiske medier som spurte seg hvor disse skulle brukes.

2I http://www.un.org/apps/news/story.asp?NewsID=20690 $\& \mathrm{Cr}=\mathrm{leban \& CrI}$

22 http://yalibnan.com/site/archives/2007/02/ban_kimoon _urge.php

24 Se bl.a. Kim Ghattas: "Lebanon's brain drain alarm", http://news.bbc.co.uk/2/hi/middle_east/6325117.stm 